\title{
Interdiszciplináris programok a vizuális kutatásban: A vizuális antropológia újragondolása*
}

Kállai Tibor fordítása

Ebben a cikkben a vizuális kutatási módszerek legújabb szakirodalmát tekintem át, mégpedig két kérdés tisztázása céljából. Elóször is megvizsgálom, hogy a legújabb interdiszciplináris kölcsönhatások milyen képet alakítottak ki a vizuális kutatás alapító tudományáról és a reprezentációról a vizuális kutatásban, elsósorban a vizuális antropológiára (és kisebb mértékben a vizuális szociológiára) koncentrálva. Másodszor pedig kritikus szemmel a szaktudományaikból vizuális módszereket átemeló, illetve azok számára ilyen módszereket bevezetó elméleti tudományok közös céljait és érdeklódési területeit. Ha elmélyedünk a vizuális kutatás „új keletú” szakirodalmában, világossá válik, hogy a különbözó szaktudományokban dolgozó mai vizuális kutatóknak vannak közös érdeklódési területeik: ilyen a reflexivitás (reflexivity), az együttmúködés, az etika, valamint a tartalom, a társadalmi kontextus és a képmások (images) anyagszerúsége közötti kapcsolat. Érvelni szeretnék a vizuális kutatómunka intenzívebben együttmúködó interdiszciplináris megközelítése mellett, amelyben az egyes szaktudományok anélkül tanulhatnak egymástól, hogy narratív sallangokkal kellene bizonygatniuk saját tudományáguknak a többiekkel szembeni felsóbbségét.

\footnotetext{
${ }^{1}$ Sarah Pink a Loughborough University Társadalomtudományi Tanszékének (Department of Social Sciences) elóadója. Kutatási területe a vizuális antropológia, az alkalmazott antropológia, valamint a nemek és az érzékelés (gender and the senses). Publikációi között említést érdemel a Doing Visual Ethnography [A vizuális etnográfia gyakorlata] (Sage, 2001) és a Women and Bullfighting [A nók és a bikaviadal] (Berg, 1997).

"Sarah Pink: Interdisciplinary agendas in visual research: re-situating visual anthropology. Visual Studies, Vol. 18, No. 2, 2003.
} 
704 TELEPÜLÉSKUTATÁS - VIIII. INTERPRETÁCIÓ

\section{Bevezetés}

A vizuális antropológia és a vizuális szociológia a XXI. század elején már elismert akadémiai segédtudománynak számít: szakmai szervezetek képviselik, és egyetemeken tanítják óket. Más tudományágak, mondjuk a kultúrakutatás, a devianciakutatás (beleértve a meleg megközelítéseket), a kulturális geográfia, valamint a fogyasztói viselkedés kutatása egyre gyakrabban alkalmaznak vizuális módszereket, s olyan megközelítésmódokat fejlesztenek ki, amelyek egyszerre szaktárgyspecifikusak, ugyanakkor sokat merítenek a vizuális antropológia létezó példáiból. A vizuális kutatásnak van elméleti és alkalmazott tudományi vetülete is. Egyre szorosabban integrálódik az antropológiai kutatás fóáramába, és egyre gyakrabban fordul felé az üzleti világ is, amit a „multik” és a kereskedelmi kutatóügynökségek bizonyítanak, amelyek portfolióikon belül etnográfiai módszereket alkalmazó fotókat és videofelvételeket kínálva hirdetnek az interneten. $^{2}$

Ahogy a vizualitás (mint olyan) egyre nagyobb szerephez jutott az elméleti és a nem elméleti társadalomtudományi kutatásban és leírásban, a különbözó szaktudományok kvalitatív kutatói érdeklódéssel fordultak a vizuális antropológia és szociológia meglévố szakirodalma felé, hogy továbbfejlesszék és információkkal gazdagítsák a munkájukat. De ahogy arra Pauwels is figyelmeztet, az interdiszciplinaritás ösvénye „egyáltalán nem egy könnyen járható út”, mivel „a szaktudományok határainak átlépésekor mindig ott leselkedik az "amatörizmus" veszélye. Ez kifejezódhet például az elképzelések és technikák gyors (és nem letisztult) cseréjében vagy átvételében, azok teljes implikációjának megértése nélkül" (Pauwels, 2000: 12-13.). Ráadásul néhány interdiszciplináris átvétel durván kritizálható és alulinformált volt. Gyakran elófordul a korábbi munkák elítélése is, amely a nagyon is hiányos háttér-olvasottságra támaszkodó, körültekintés nélküli és félreinformált interdiszciplináris kölcsönösségnek az eredménye. A kritikák gyakran olyan narratív stratégia formáját öltik, amely a szerzó saját megközelítésének felsóbbrendúségét kívánja bizonyítani.

Ez egy áttekintố írás, amelyben két kérdést vizsgálok. Elốször is, a vizuális antropológiára (és kisebb mértékben a vizuális szociológiára) koncentrálva megvizsgálom, hogy a legújabb interdiszciplináris kölcsönhatások milyen képet festettek az alapító tudományágakról a vizuális kutatásban és leírásban. Ezek a

\footnotetext{
${ }^{2}$ Például „az angol Everyday Lives kutatóintézettel és a Giant Mars Inc. édesipari céggel együttmúködve ez la Proctor and Gamble] olyan videofelvételek internetes archívumát alakítja ki, amelyek otthonukban, mindennapi ténykedésük közben mutatják az embereket", a Kodak pedig antropológusokat alkalmaz a fotográfia etnográfiai kutatására (Anthropology Today, 7 (4): 28, 2001., és 18 (2): 31, 2002.).
} 
bírálatok a diszciplináris egyediséget hangsúlyozzák, de rámutatnak a kölcsönös érdeklódési területekre is. Ezért aztán, másodszor, kritikai szemmel áttekintem a szaktudományaikból vizuális módszereket átemeló, illetve azok számára ilyen módszereket bevezetó elméleti tudományok közös céljait és érdeklódési területeit. Ha elmélyedünk a vizuális kutatás „új” szakirodalmában, világossá válik, hogy a különbözó szaktudományokban dolgozó mai vizuális kutatóknak igenis vannak közös érdeklódési területeik: ilyen a reflexivitás (reflexivity), az együttmúködés, az etika, valamint a tartalom, a társadalmi kontextus és a képmások (images) anyagszerúsége közötti kapcsolat. ${ }^{3}$ Meglehet, nem tudok majd ellenállni a kísértésnek, hogy elótérbe ne toljam saját szaktudományomat, az antropológiát. Mindazonáltal érvelni szeretnék a vizuális kutatómunka intenzívebben együttmúködó interdiszciplináris megközelítése mellett, amelyben az egyes szaktudományok anélkül tanulhatnak egymástól, hogy narratív sallangokkal kellene bizonygatniuk saját tudományáguknak a többiekkel szembeni felsóbbségét.

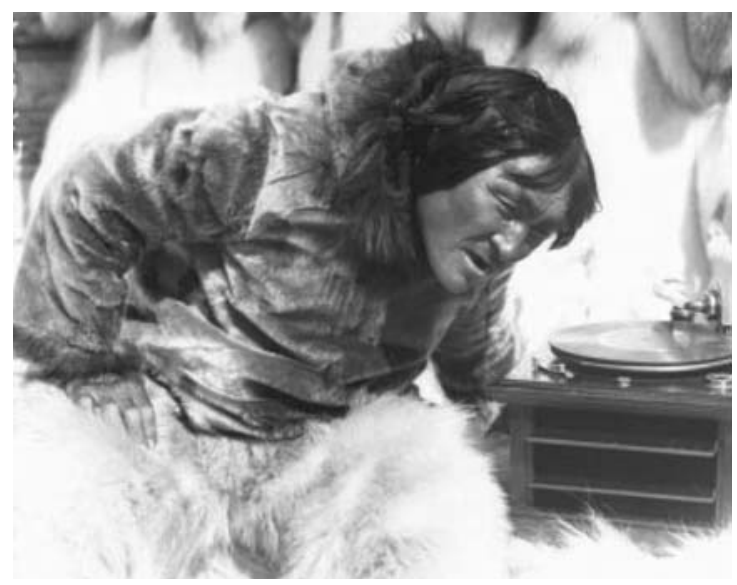

I. ábra. Nanuk fotója, melyet Robert Flaherty készített a filmezés során. A New York-i International Film Seminars szívességéből.

\section{A vizuális antropológia kritikái: $A$ XX. század értékelése}

A vizualitás antropológiai használata terén a hangsúly fokozatosan eltolódott a XX. század közepére jellemzó realista vizuális megörökítési módszerekról a késóbbi egyesített és kortárs megközelítésmódok felé, amelyek a szubjektivitást, a reflexivitást és a vizuális koncepcióját mint ismeretet és kritikus „hangot” helyezik elótérbe. Ezt a változási folyamatot alakító elképzelést jól dokumentálja a legújabb szakirodalom (Grimshaw 2001; Pink 2001a). Ez magában foglalja a reprezentáció kritikai perspektíváit és új elméleteit, a reflexív és együttmúködó (collaborative) etnográfiai módszereket, a vizuális materialitását és hatóerejét, valamint a vizuális jelentések kétértelmúségének felismerését. Ezek a változások

${ }^{3}$ A képmások anyagiságának témája jobban érdekli az antropológusokat, mint más tudományágak múvelóit, de ebben a cikkben részletesebben nem foglalkozunk vele. 
706 TELEPÜlÉSKUTATÁs - VIII. INTERPRETÁCIÓ

akkor következtek be, amikor az antropológia olyan szaktudománnyá vált, amely kritikailag reflektál saját gyakorlatára és elméleteire, és amelyben az antropológusok kritikai észrevételeket tettek és innovatív megoldásokat alkalmaztak új gyakorlatok és megközelítésmódok kifejlesztésére.

Ebben a fejezetben három olyan esettel foglalkozom, amelyról alapos tájékoztatást kínál a vizuális kutatáshoz kötốdó elmélet és gyakorlat fejlódésének története és annak reprezentációja: nyomtatott szöveg, fotó és film formájában. Példáim a következók: Robert Flaherty Nanook of the North (Nanuk, az eszkimó, 1922) címú filmje, Margaret Mead és Gregory Bateson Balinese Character (1942) címú fotótanulmánya, és E. E. Evans-Pitchard fényképhasználata a The Nuer (1940) címú munkájában. Miután megvizsgálom, hogy ezek az esetek miként jelentek meg a legújabb interdiszciplináris vitákban, felvázolom, hogy miként értelmezték és értékelték újra óket különbözó elméleti és módszertani perspektívákból, s hogy az óket kíséró viták miképpen tükrözik az etika, az objektivitás/szubjektivitás, a realizmus és igazság, valamint a reflexivitás korabeli kezelését.

\section{FLAHERTY ÉS NANUK: ÖNTUDATOS VAGY ÖNIGAZOLÓ?}

Az inuit (eszkimó) kultúráról készült egyik legkorábbi dokumentumfilm, Robert Flaherty Nanook of the North (magyarul: „Nanuk, az eszkimo”) címú alkotása 1922-ben jelent meg. Flaherty nem volt antropológus, de filmjét az antropológiában máig akkora tisztelet övezi, hogy érdemes lesz itt is szólnunk róla. A mú egy „másik” és „ismeretlen” kultúrára vonatkozó tudást képvisel a film narratív eszközeinek felhasználásával. A film Flahertynek az inuitok életével kapcsolatos tapasztalataira és megfigyeléseire támaszkodik (Grimshaw 2001: 47.), és akárcsak a XX. század eleji Malinowski-féle antropológiát, egyfajta humanista megközelítés jellemzi, valamint olyan „romantikus érzület, amely megszabja a világhoz való hozzáállásunkat" (Grimshaw 2001: 46.). A Nanuk változó módon volt jelen a vizuális antropológiában. Banks „még diák volt, amikor az 1970-es években bemutatták neki Flaherty Nanuk címú filmjét, de nem a korai dokumentumfilm-stîlus egyik példájaként, vagy akár az idegen kultúra reprezentációjának kérdéseit felvetó alkotâst, hanem a bennszülött alaszkai kultúrára nyiló, látszólag közvetlen ablakként" (2001: 148.). 1989-90-ben egyetemistaként más körülmények között, az elsó etnográfiai filmnek titulálva, a reprezentáció, a rekonstrukció és a filmstílus kérdéseire koncentrálva láttam a Nanukot. Ebben a kontextusban a Nanuk egy rekonstrukció példája volt. Egy olyan stílusé, amelyet illetoóen az 1990-es évek elején, amikor a realista megközelítésmódoknak volt jelentósebb súlyuk, az antropológusok még bizonytalanok voltak. 
Készítésének idején a Nanuknak még más volt a jelentốsége, éppen ezért a „Rendkivüli! Izgalmas! Drámai!” jelzókkel reklámozták. A nézóket ilyen mondatokkal csábították a moziba: „Lássák az életért folyó harcot a jeges sarkvidéken!”, és „Nézzék, amint Nanuk megszigonyozza a fókát, küzd az elejtéséert, s azután nyers húst eszik!' Azt mondták az embereknek, hogy „nem fognak hinni a szemüknek, annyi az érdekesség, annyi az izgalom, annyi a szivdobogtató szenzáció, hogy úgy fognak ott ülni, mint akit megbabonáztak. Ritkán látható dráma, nagy sztori, izgalmas akció, döbbenetes emberi átütóeróvel. Kétszer fogják megnézni, és örökké beszélni fognak róla" (a film reklámplakátjának reprodukciójáról, Gaines 1999: 9.). Ez az 1920-as, szenzációhajhász reklám bizony a film olyan értelmezésére csábíthatott, mely szerint ez egy egzotizáló projekt, amely egyszerre játszik rá a sokkolóra és az ismerósre, s így ábrázolja a kulturális különbségeket. Ezt az értelmezést Rony vetette fel, aki szerint a Nanuk „a romantikus prezervacionizmus filmje, amely nem az antropológiai ismeretszerzést kívánja szolgálni, hanem a bennszülöttek trófeaként való bemutatását és életmódjuk nosztalgikus fikcióban való rögzítését" (Rony 1966: 102., idézi Gaines 1999: 6.). Gaines leírja, hogyan alkalmazza Rony az „etnográfiai taxidermia” Haraway-féle fogalmát annak kifejtésére, hogy a film mesterséges megoldásokat alkalmaz „egy olyan realitás produkálására, amely feljavítja a kamera elótti eseményt, dúsitott és kiegészített valóságot hozva létre, amely valóságosnak és igaznak akarja elfogadtatni magát" (1999: 7.). Gaines azonban rámutat, hogy miközben a Nanuk tényleg produkálhat egy „pótvalóságot” (supplemented reality), Rony észrevételei nem teljesen megalapozottak, mivel figyelmen kívül hagyják, hogy Flaherty a filmben „ószintén keresi a teljesen ismeretlenre és a jól ismertre vonatkozó tudást". Fentebb már említettem, hogy a reklám is a jól ismertre és a sokkolóra hivatkozott, vagy ahogy Gaines fogalmaz, „a hasonlósággal való közönséges búvészkedésre”, amely „támogathatja a hasonlatosság funkcióját, mint a megismeréshez vezetó utat" (1999: 7.). Így tehát Gaines sajátos módon rehabilitálja Flaherty narratív stratégiáját, mint az ismeretlenre vonatkozó ismeret közlésének olyan módját, amely megteremti a hasonlóságot a jól ismerttel, ekképpen kínálva a közönségnek azt a keretet, amelynek segítségével megértheti és befogadhatja az új ismeretet.

Gaines kifejti, hogy a Nanuk nem arról akarja meggyó́zni a nézóket, hogy ók az inuit élet közvetlen valóságát látják. Visszautalva a reklám szövegére, Gaines azt mondja, hogy „a közönséget vonzza a megtévesztés és magának a megtévesztésnek a sikere is - a készitónek az a képessége, hogy tökéletes illúziót keltố imitációt produkáljon" (1999: 8.). Rony elemzésének az a fogyatékossága, hogy a filmre úgy tekint, mint szövegre. A film tartalmára, s nem készítésének és közönségének szélesebb összefüggéseire koncentrálva - Rony - a filmet az akadémiai elemzés szúk prizmáján keresztül értelmezi, amely az idegen kultú- 
rák antropológiai reprezentációit tévesen az igazság-követelések objektivációjának minósíti. Gaines saját fejtegetéséból azonban szintén hiányzik egy fontos dimenzió, minthogy nem foglalkozik a filmkészítés folyamatával vagy készítóik intencionalitásával.

Jay Ruby vizsgálta a film készítését és formáját, valamint Flaherty módszereit és szándékait, s ebból kiderül, hogy milyen fontos figyelembe venni a vizuális reprezentációk elkészítésének körülményeit. Ruby bírálja is Ronyt, rámutatva, hogy annak „Flahertyvel és a Nanukkal foglalkozó fejezete megalapozatlan állitásokkal van tele" a filmkészítési folyamat gyakorlatát illetóen, s ez tarthatatlanná teszi a szerzó álláspontját. Ebben Ruby az arra irányuló kísérlet egy példáját látja, hogy „bírálják az antropológiát és az etnográfiai filmet anélkül, hogy bármelyikról is elegendó, a hiteles érvelést lehetóvé tevó ismeretekkel rendelkeznének" (Ruby 2000: 283.), s Rony munkáját velósen "politikailag korrekt Flahertypüfölésnek” (2000: 69.) minósíti. Ruby viszont a Nanukot „narratív filmnek” nevezi, amelyben Flaherty „aktualitással keveri a drámai történetet” (2000: 71.). Gaineshez hasonlóan Ruby a megismeréshez vezetó útként üdvözli a narratíva használatát, hangsúlyozva, hogy a narratíva nemcsak a fikciós film egyik sajátossága, hanem olyan dokumentációs eszköz, amelynek az etnográfiai filmben is megvan a maga szerepe. Párhuzamot lát Flaherty és a kortárs etnográfiai filmkészítók produkciós módszerei között, leszögezve, hogy Flaherty „a résztvevó és reflexív film egyik uittöróje volt” (2000: 83.). Flaherty munkásságának és felesége naplójának illetve levelezésének Ruby által történó elemzéséból például kiderül, hogy Fraherty milyen szorosan együttmúködött fószereplójével, Nanukkal, hogy olyan filmet hozzon létre, amely az inuit mindennapi élet, valamint a dramatizált események általuk közösen megalkotott konstrukcióján alapul.

A Nanuk vitája azt példázza, hogy a vizuális antropológia történetének meghatározására irányuló kortárs próbálkozások miképpen koncentrálnak a reflexivitás, a konstruáltság (constructedness), a realizmus és az etika kérdéseire. Miközben Rony kisajátítja az igazság-követelések objektivációjának népszerú posztkoloniális kritikáját, Ruby azt állítja, hogy Flaherty öntudatos (self-aware) projektre vállalkozott, melyben együttmúködött alanyaival, hogy közösen olyan filmet hozzanak létre, amely a drámai események rögzítésével mutatja be mindennapi életüket a szélesebb közönségnek. Ruby tehát etikusnak minósíti Flaherty vállalkozását, amely tudatosítja alanyainak nézeteit és leplezetlenül konstruált jellegú. A Nanuk a realizmus koncepcióival játszik. De mert reprezentálni kívánja a mindennapi életet, nem tart igényt arra, hogy a reális idóben megélt valóság objektív rögzítése legyen, s valószínúleg a közönség sem is ilyennek tekintette. 


\section{Mead és Bateson Bali szigetén, valamint Evans-Pritchard Nuerje: EGYEDÜLÁLLÓAN INNOVATÍV, AVAGY EGZOTIZÁLÓ ÉS OFFENZÍV?}

Margaret Mead fotós és filmes munkái - valamint arra irányuló erófeszítései, hogy a vizuális dolgokat elótérbe helyezze a társadalomtudományi kutatásban tartós hatással voltak a vizuális antropológia és a vizuális szociológia fejlódésére. Mindkét tudományág szakírói gyakran idézik írott és vizuális munkáit s azt a felhívását, mely szerint társai nyugodtan használják a képeket - híres kifejezésével - a „Szavak tudományágában” (1975). Mead rámutatott, hogy a vizualitást fel lehet használni a korabeli társadalomtudományi kutatások céljainak támogatására - vagyis az „objektív” adatok realista rögzítésének támogatására, amelyeket aztán antropológiai kutatás céljából lehet elemezni. Mead a „megfigyelóinek” (observational) nevezhetó megközelítésmód korai példáját kínálja. Ahogy Banks kifejti: egy feltevést, „mely szerint egyszerüen megfigyelni valakit, annyit tesz, mint megtudni róla valamit”, ami által tulajdonképpen létrehozunk „egy késóbb elemezhetó és szellemi tókévé alakitható ismeretet" (Banks 2001: 112.). Banks valójában Hocking Principles of Visual Anthropology (A vizuális antropológia alapelvei) címú kötetének Mead-fejezetére hivatkozik (1995 [1975]).

A megfigyelói megközelítés Mead korában fontos jellemzóje volt a társadalomkutatási módszereknek, és Mead maga is törekedett a vizualitás ilyen irányú alkalmazására. Az antropológiai „látásmódok” történelmi fejlódésének menetében ez az az idôszak volt, amelyben „sok energiát forditottak az etnográfiai film elfogadható tudományos vállalkozásként történó legitimációjára" (Grimshaw 2001: 88.). Több mint 25 évvel késóbb ez már „reménytelenül elavultnak túnik” (Banks 2001: 112.), mivel a legtöbb antropológus azokat a folyamatokat, amelyek révén a kutatás menetében megszerzik az ismeretet, inkább a kutató és az adatközlók közötti kapcsolat és egyezkedések eredményének tekinti, s nem az utóbbiak elóbbi által történó objektív megfigyelésének. Azóta a vizuális antropológia kétségtelenül elórehaladt. Ugyanakkor a vizuális antropológiában megjelent elképzelések és eszmék történetének néhány mostanság megjelenó félreértelmezése Mead 1975-ös felvetéseit úgy jellemzi, mintha azok dominánsak lettek volna akkortájt. Holliday (2000) például Mead - 1995-ben újra megjelent - álláspontját objektív megközelítésmódnak tartja, s ezt tekinti a XX. század végi vizuális antropológia jellemzó megközelítésmódjának. Meadet kritizálva azonban minden esetben történeti összefüggésekbe kell helyezni munkásságát. S minthogy Mead 1978-ban elhunyt, az ó elképzelései nem képviselhetik az 1990-es évekbeli vizuális antropológia karakteres szemléletét (lásd Pink 2001b).

Mead és Bateson Bali szigetén végzett korábbi, Balinese Character címú könyvükben ismertetett munkája, amelyben a fényképezést alkalmazták megfi- 
TELEPÜLÉSKUTATÁS - VIII. INTERPRETÁCIÓ

gyelói vizuális rögzító eszközként, szintén témája lett a kortárs vitáknak. Banks (2001: 120-121.) is említést tesz róla, és ezzel szemlélteti, hogy a társadalomkutatók hogyan használták a félig leplezett kutatási technikákat adatközlóik öntudatlan (unself-conscious) képmásának elóállítására. Az adatközlók tudják ugyan, hogy a kutató fényképez, de azt már nem tudják, hogy pontosan mit. Ahogy Banks írja:

\begin{abstract}
„Kvázi-etnológiai munkájában Bateson (...) néba anguláris képkeresós állóképes kamerát használt, amikor Margaret Meaddel együtt a Bali-szigeti teststílusokat (body styles) kutatta, ami nyilvánvalóan lehetóvé tette számára, hogy úgy azonositson és szerkesszen meg egy felvételt, "amikor arra lebetett számitani, bogy az alanynak nem fog tetszeni, ha éppen abban a pillanatban fényképezik" (Bateson és Mead 1942: 49.). Az általa felbozott példa, a közös munka 29. lemeze, a 8 képból álló Eating meals (Étkezés) címú fotósorozat, amelynek képaláirása a következô: "Az étkezéshez jelentós fokú szégyenérzet társul. Akik esznek, általában bátat fordítanak mindenkinek, ki netán jelen van"” (Bateson és Mead 1942: 112.). (Banks 2001: 120-121.)
\end{abstract}

Banks jól látja, hogy hol helyezkedik el Mead és Bateson munkája a 60 évvel ezelótti antropológiában. Megjegyzi, hogy etikai megfontolásokból nem sok kortárs kutató helyeselné a teljesen rejtett kutatást (2001: 120.), bár explicit módon nem mond ítéletet a Mead és Bateson által alkalmazott stratégiákról. A történeti szempont döntó jelentốségú. Objektív vizuális adatok gyújtésének reményében Mead és Bateson nem akarta, hogy képeiket befolyásolja az adatközlók tudatossága (vagy a fotózással szembeni ellenkezés). Minthogy ók egy saját etikai követelményekkel rendelkezó tudományos antropológia programjának keretében dolgoztak, etikájuk helyett inkább ezt a megközelítést átható elméleti és módszertani elképzeléseiket és hiedelmeiket (beliefs) kellene bírálni. Ráadásul Mead még meg is tanította helybéli balinéz segítóit, hogy kritikai szemmel minósítsék a Batesonnal róluk készített filmanyagokat (Banks 2001: 120.), ami arra utal, hogy Mead nyitott volt az általuk készített felvételekkel kapcsolatos észrevételekre, és együttmúködött az adatközlókkel, hogy megértse óket. 

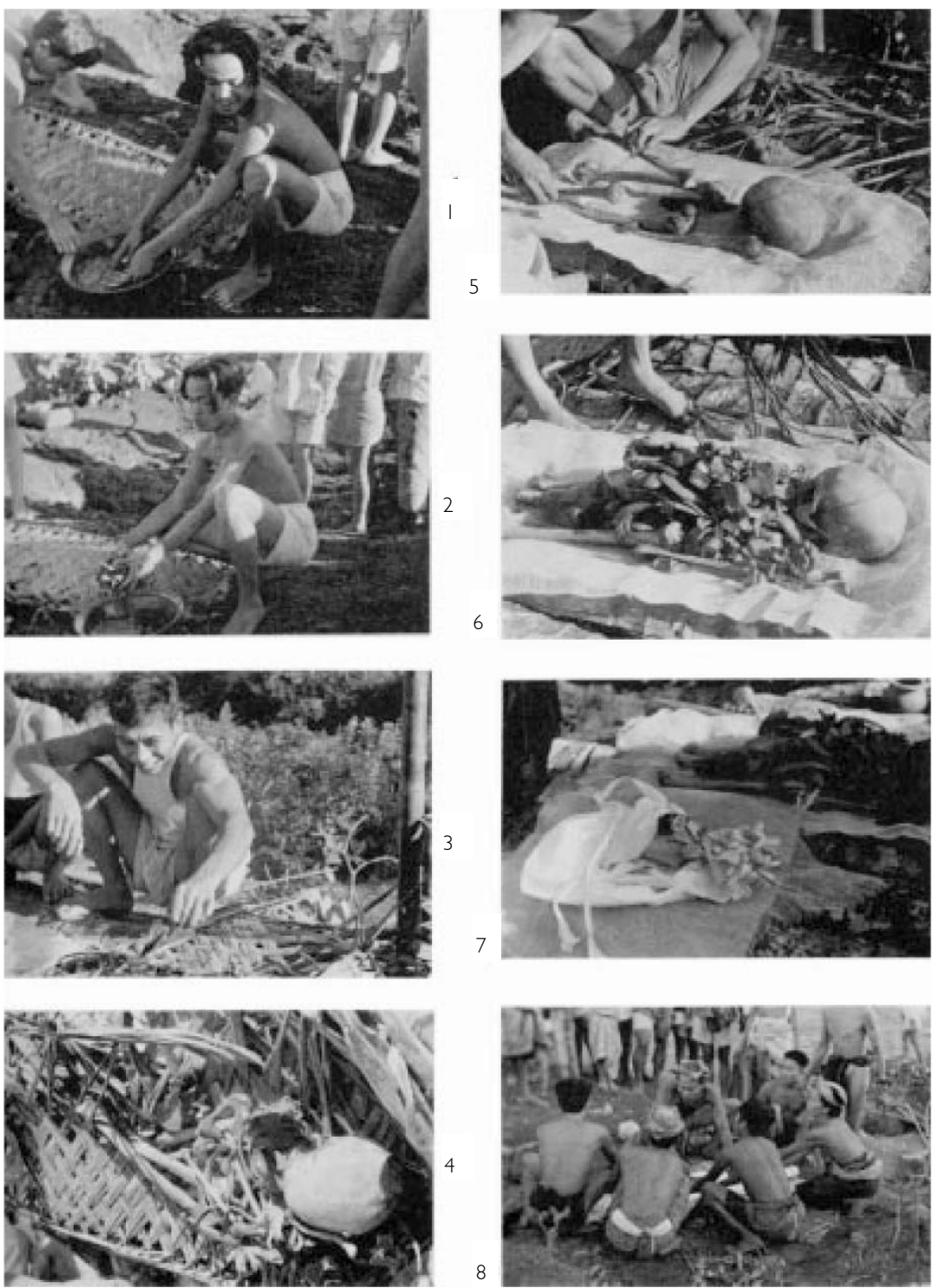

I. és 2. ábra. Egy brahman mossa a csontokat. Figyeljük meg, hogy nevet, de kinyújtott kézzel dolgozik, hogy testét ne érje a kifröcskölő víz.

3. ábra. Egy brahman fiú játékosan elkezdi kirakni a csontokat, amelyek a mosás után hozzá kerültek.

4. ábra. A koponya és más csontok a megmosás után kókuszlevél-fonatra helyezve.

5. ábra. A hosszú csontok és a koponya kirakása a test alakjának megfelelően. A csontokat pálmafonatra terített, laza szövésű, krémszínű szövetre helyezik.

6. ábra. A kisebb csontokat most rászórják a hosszú csontokra.

7. ábra. A csontokból kirakott testet és a lelket reprezentáló bábut (sanggah oerip) most egymás mellé rakják. A kép előterében a pálmafonaton a sanggah oerip, azzal a ruhával (anteng) együtt, amelyben hozták; jobbra fent az a fekete tömeg a csonthalom.

8. ábra. A test végső beburkolása pálmafonatokba. Ez a művelet a holttest temetéskori beburkolásának megismétlése. 
A Mead és Bateson Bali-projektjéról szóló más írások a reprezentációra koncentráltak. Chaplin (1994: 232.) arról beszél, hogy Mead újító módon használta a képet és a szöveget a Balinese Character tervezetében. Chaplin konstruktív elemzést kínál arról, hogy ezeket a képeket hogyan használják a tudás reprezentálására. Emmison és Smith (2000) elemzése azonban már nem ennyire megértó. A Flahertyról mondott Rony-féle kritikához hasonlóan a szerzópáros is a kolonializmust hozza szóba, hogy bírálja Bateson és Mead (1942), valamint Evans-Pritchard (1940) munkáját, valamint hogy az egész vizuális antropológiát tévúton járó, nem túl hasznos küldetésnek minósítsék. Kijelentik, hogy az elóre vezetó utat a vizuális kutatás általuk képviselt megfigyelói megközelítésmódja jelzi, és etikai alapon bírálják a vizuális antropológiát, mert magáévá tett egy olyan „dogmatikus álláspontot, miszerint a szövegeikhez vizuális anyagokat is kell csatolni, még olyanokat is, amelyek erósen offenzív jellegúnek minósithetók". Példaként említik Bateson és Mead (1942) Balinese Characterének néhány képét, amelyek alatt a következók olvashatók: „rituális önsebzés (...), holttestek rituális célú exhumálása (...), és egy kutya, amely egy földön mászó csecsemóbót potyogó ürüléket fogyaszt”. Azt írják, hogy a fotók ilyen használata egy stratégia, amely - a koloniális diskurzus kontextusában - az olvasóinak „egy olyan érzést kinál az iránt a társadalom iránt, amellyel foglalkoznak", amely lehetóvé tette az antropológusok számára, hogy tárgyait (objects) az ábrázoltak részéról megnyilvánuló cenzúrától nemigen tartva mutassa be. „A földrajzi, a kulturális és a rasszbeli távolság lehetóvé tette, hogy az etnográfiai fotót semleges és tudományos dokumentumnak, nem pedig pornográf vagy voyeurisztikus, kihasználó vagy potenciálisan korrumpáló jellegünek állitsák be.” Egyebek közt és fóként azokat a közelképeket említik Evans-Pritchard (1940) munkájából, amelyeken mezítelen nuer nók és férfiak a nemi szerveiket mutogatják (Emmison és Smith 2000: 15.).

Emmison és Smith kritikája nem teljesen téves, de nem is egészen újszerú. Valójában már több, részletezóbb (általuk nem idézett) kritika született meg a gyarmati fotográfia vizuális szakirodalmával kapcsolatban a vizuális antropológiában (lásd pl. Edwards 1992, 1997). Evans-Pritchard nuer-fotóiról szólva Hutnyk azt is megemlíti, hogy az egyik kép hogyan ábrázol szemból két teljesen mezítelen férfit: „ezek a névtelenül az elótérbe állitott bennszülöttek differenciálatlan, összehasonlitásra kész "nuer" fajtársak" (1990: 90.). Hutnyk kimutatja, hogy a fotók ilyetén használata elénk állít egy sor általános nuer típust - férfi, fiú, ifjú stb. -, fotográfiailag ezzel „egy komplex entitás leegyszerúsitett modelljét” teremtve meg (1990: 90-91.). Ezt a modellt könnyú összevetésre felhasználni. A képaláírások pedig „a koloniális és antropológiai lumpen-kategorizálás szimbólumait” alkalmazzák olyan megjelölésekkel, mint például „fiú”, és azzal a „kontextuális rasszizmussal", amit ez a terminus hordoz (1990: 95.). 


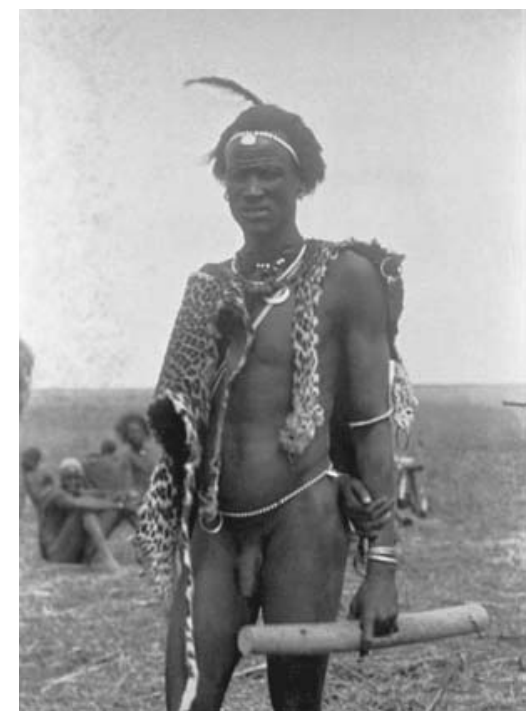

3. ábra. Egy leopárdbőrbe öltözött törzsfőnök. XXVI. tábla; in: Evans-Pritchard: The Nuer (1940). A Pitt Rivers Museum, University of Oxford szívességéből [Accession No. EP. N. 362].

Azok a kritikai észrevételek, amelyeket Emmison és Smith a vizuális antropológia elutasítása során felvet, már korábban is megfogalmazódtak, s ahogy Loizos kimutatta a pornográfia és az etnográfia Nichols-féle összevetésére (1991) adott válaszában, az analógia egyszerúen nem múködik (Loizos 1993: 206-207.). Ráadásul az antropológiában, Emmison és Smith kommentárjától eltérốen a létezó kritikák kiindulási pontként fogalmazódtak meg annak vizsgálatához, hogy miként kell elkészíteniük más kultúrák megfeleló fotográfiai reprezentációját a helybéli lakosokkal együttmúködó antropológusoknak, illetve a bennszülött fotográfusoknak. Az antropológusok és a fotográfusok közötti együttmúködés egyik jó példája, amely kritikai válaszokat adott a vizuális médium használatának ezekre a megközelítésmódjaira, az a Royal Anthropological Institute és a Photographer's Gallery által indított „Visible Evidence" (Látható bizonyíték; 1995) elnevezésú projekt. Emmison és Smith sok ilyen újabb keletú kezdeményezést hagy figyelmen kívül, nem vesz tudomást az 1942 után végzett kutatásokról, és sem történetileg, sem pedig elméletileg nem tudja a helyén kezelni a Mead és Bateson, valamint az Evans-Pritchard által végzett munkát. Kurtán-furcsán lenullázzák az antropológiának azt az igényét, hogy reflexív és etikus vizuális diszciplína legyen, anélkül hogy foglalkoznának annak az elmúlt 60 évben mutatott fejlódésével és önkritikájával, illetve azzal a ténnyel, hogy az antropológiát manapság nagyrészt vagy „otthon” múvelik, vagy pedig olyan antropológusok képviselik, akik nem a modern nyugati kultúrákból érkeztek (lásd Moore 1999).

A Flaherty, Bateson és Mead, valamint Evans-Pritchard írásaira támaszkodó antropológia-bírálatok egyik kulcsproblémája az, hogy képtelenek készítésük és látásmódjuk (viewing) történelmi kontextusába helyezni a korai antropológiai vizuális képmásait és eljárásait. Ezenkívül önmagát korlátozó momentum itt az is, hogy érvelésében Emmison, Smith és Rony a kolonializmus bírálatára van utalva. Legújabban Edwards (2001) foglalkozott történelmi fényképek egy sorozatával, és kimutatta, hogy azt a kérdést, hogy „a fényképek és készitésük valójában miképpen múködtek az ideológiai és kulturális jelentés cseppfolyós terveiben (...) nem mindig lehet pontosan összefoglalni a recepcióelmélet, a szemiotika 
vagy a posztkoloniális dekonstrukció mechanizmusai révén" (2001: 3.). Ehelyett azt javasolja, hogy történeti értelemben koncentráljunk a fotográfiai gyakorlat és tapasztalat egyes specifikus aktusaira.

\section{A vizuális kutatás kortárs perspektívái: a vizuális módszerek új interdiszciplináris területe?}

Fentebb az interdiszciplináris versengést emeltem ki. Erról késóbb még bóvebben szólok. Ugyanakkor, ahogy azt a publikációk és a szakmai konferenciák is jelzik, kialakulóban van egy multidiszciplináris érdeklódési terület, amely a társadalomkutatásban a kutatás és a leírás vizuális módszereinek alkalmazására koncentrál. A van Leuwen és Jewitt által szerkesztett Handbook of Visual Analysis (A vizuális elemzés kézikönyve, 2000) címú multidiszciplináris gyújteményes kötet a pszichológiából, a szemiotikából, a kultúrakutatásból, az antropológiából és a médiakutatásból említ példákat a vizuális kutatási módszerek alkalmazására, és jól érzékelteti, hogy a vizuális kutatók nemcsak a különbözó módszereket kívánják kombinálni, hanem a különbözó diszciplináris felismeréseket is. Rose Visual Methodologies (Vizuális metodológiák, 2001) címú munkája külön fejezetekben vizsgálja a képi megjelenítés elemzésének különbözó diszciplináris megközelítésmódjai által kínált elónyöket és buktatókat. A különbözó szaktudományok vizuális kutatói közötti vitákat elómozdította a 2000 és 2001 között megrendezett Visual Evidence (Vizuális bizonyíték) elnevezésú szemináriumsorozat. ${ }^{4}$ Ez azt jelzi, hogy a különbözó szaktudományok vizuális kutatóinak részben hasonló a szemléletük, s hogy a jövóben a vizuális kutatás a szaktudományok közötti szorosabb együttmúködés eredményeképpen interdiszciplináris és multidiszciplináris szakterületté is fejlódhet. Ebben a fejezetben ennek két aspektusával foglalkozom: az elsó az újabb publikációk eredetiségigénye a vizuális módszerekkel kapcsolatban; a második pedig az érveléseikben és kritikáikban benne foglalt közös témák: a tartalom, a kontextus és a kép materialitása közötti kapcsolat, valamint a reflexivitás és az etika, az együttmúködés, és nem utolsósorban a szubjektivitás/objektivitás kérdése.

\footnotetext{
${ }^{4}$ Az Economic and Social Research Council szemináriumsorozata, amelynek az Open University, a University of Leeds és a National Portrait Gallery (London) adott otthont 2001-ben, s amelyet Jon Prosser, Rob Walker és Peter Hamilton rendezett meg.
} 


\section{A vizuális képmások értelmezése}

Azt igyekszem bizonyítani, hogy a kutatónak minden projektben nem csupán a képmás belsó ,jelentéseivel” kell foglalkoznia, hanem azzal is, hogy miképpen jött létre az adott képmás, s hogy miképpen teszik ,jelentésessé” (meaningful) azt a szemlélók. S a Nanook of the North Rony-féle kritikájának épp az az egyik fogyatékossága, hogy nem érinti e kérdések mindegyikét. Ezt a három területet a vizuális módszerek szakírói is kiemelik. Az antropológus Banks például ekként foglalja össze a lényeget:

„A képek szélesebb értelemben vett társadalmi kutatása három kérdéskört vet fel: (1) mi a képmás és mi a tartalma?; (2) ki választotta vagy készítette azt, mikor és miért?; és (3) hogyan tettek szert rá mások, bogyan olvassák azt, mit csinálnak vele?” (Banks 2001: 7.).

A kultúrgeográfus Rose nem annyira a képmások társadalmi használatára koncentráló antropológiából és szociológiából merít, mint inkább a vizuális képmások és szövegek tanulmányozásával foglalkozó szaktudományokból (fotográfia, pszichológia, vizuális kultúra, kultúrakutatás és médiakutatás). Ugyanakkor foglalkozik a társadalmi és a textuális vonatkozásokkal, és kitart egy „kritikai” vizuális metodológia mellett, támogatva egy olyan megközelítést, amely „a vizuálisról a kulturális jelentóség, a társadalmi gyakorlatok, valamint a vizuális szemléletéból fakadó hatások kategóriáiban gondolkodik, figyelembe veszi a különféle közönség általi szemlélet specifikusságát" (2001: 32.). Háromszintú elemzést javasol, amely egy vagy több területre (site) koncentrálhat, ahol a képmások jelentései létrejönnek: az elóállitás területére; magára a képmásra; és az általa - a Fiske-tól (1994) kölcsönzött terminussal - „audiencing”-nek (kb. „közönségezés“) nevezett jelenségre, vagyis „arra a folyamatra, amelynek révén egy vizuális képmás jelentéseit átértelmezik (renegotiated), vagy akár el is vetik a specifikus körülmények között szemléló konkrét közönségek" (2001: 5.). E három szinten belül Rose három modalitást különböztet meg: a technikait (technological), a kompozicionálisat és a társadalmit. Azt állítja, hogy e modell révén megérthetjük a képmások értelmezéséról folyó elméleti vitákat is, amelyek Rose szerint „arról szólnak, hogy e területek és modalitások közül melyik játssza a legfontosabb szerepet egy képmás megértésében" (2001: 32.).

A mostani megközelítésmódok Rose-féle kritikája és a szerzó eredetiségigénye abból a meggyózódésból fakad, hogy a vizuális jelentések „társadalmi” aspektusai több figyelmet érdemelnek. Az antropológusok már egy ideje ugyanezt mondják. Banks például egy olyan modellt javasol, amelynek segítségével meg lehet érteni a kapcsolatot a társadalmi kontextus és az egyes képmás tartalma 
között. Elvetve azt az elképzelést, hogy egy képmást úgy lehet olvasni, mintha egy „belsố” üzenetet tartalmazna, amelyre „hallgathatunk”, Banks kifejti, hogy a képmások „olvasásához” azok külsó és belsó narratíváit kell figyelembe vennünk. Egy kép tartalma egyfelól annak „belsó narrativaája - a sztori, ha úgy tetszik - és a társadalmi kontextus, amely létrehozta a képmást és azokat a társadalmi relációkat, amelyekbe a képmás a szemlélése minden pillanatában beleágyazódik”. Ez utóbbi a képmás külsó narratívája (2001: 11-12.). Banks kitart amellett, hogy a vizuális képmások jelentésének megértésében a társadalmi relációk játsszák a kulcsszerepet. Például „minden film, fénykép és múalkotás emberi tevékenység terméke, és különbözó mértékben kötódik az emberi társadalmi viszonyokhoz; megértésükben igy tágabb elemzési keretet igényelnek", ami Banks megfogalmazásában „a magán a vizuális textuson túlmenó külsó narrativa olvasását" jelenti (2001: 12.). Ezek az elképzelések igen elterjedtek ugyan a vizuális antropológiában és a média-antropológiában, de Rose megjegyzi, hogy az általa áttekintett mai megközelítésmódok figyelmen kívül hagyják az „audencinget”, a mindenkori befogadó közönséget. Rose - Moores (1993), Morley (1992) és Ang (1985) munkáira támaszkodva - felveti, hogy az „audiencing” tanulmányozásakor figyelembe vehetjük, hogy (a) „a közönségek hogyan reagálnak egy vizuális képmásra (...), hogy kialakitsuk annak a képmásnak egy sajátos értelmezését”, és (b) hogy „a különbözó közösségek hogyan reagálnak ugyanarra a képmásra (...), bogy demonstráljuk a dekódolási folyamat komplexitását", a one-to-one és a csoportinterjúk különbözó típusait használva (2001: 193-197.). Ez kialakítja az „audiencing etnográfiáját” (2001: 197.), amelynek lényege, hogy „az etnográfiai megközelítés szellemében a kutató hosszabb idón át a saját otthonában figyel meg egy közönséget, és beszélget vele a meglátásairól (viewing), de valószinúleg sok más dologról is" (2001: 197-198.). Erre a kérdésre még viszszatérek a következó fejezetben.

A kulturális vizsgálatok egyre gyakrabban jelennek meg a vizuális módszertani szövegekben. Emmison és Smith felvázolja a vizuális interpretációnak a kultúrakutatásban lehetséges interdiszciplináris fogalmi „eszköztárát” (2000: 66-69.), Rose pedig a „vizuális kultúrák” szférájából merít (2001: 9-15.). Hasonló módon érvel: „csak ritkán vagy egyáltalán nem lehetséges elválasztani a mindennapi élet kultúráját a vizuális vagy másmilyen leírás gyakorlataitól". Lister és Wells arra vállalkozik, hogy felvázolja a vizuális analízis kultúrakutatási megközelítését - vagyis a „vizuális kultúrakutatást” (2000: 61-62.). Tanulmányuk kulcsfontosságú megállapításokat tartalmaz a vizuális kultúra kutatásának módszereiról és megközelítésmódjairól, melyek hasznosabbak, mint a külsó kultúravizsgálatokból, s köztük az enyémból (Pink 2001a) is vett korábbi magyarázatok. A kultúrakutatás módszertana eklektikus (Lister és Wells 2000: 64.; McGian 1997), és „az etnográfiai, pszichoanalitikai és szövegkritikai módszerek” használata köz- 
tudottan sokat merít más tudományágakból (Lister és Wells 2000: 63.). Analitikai projektje koherens. Lister és Wells vizuális kultúrakutatási megközelítése a következókre koncentrál: „a képmás társadalmi életére és történetére”; „az elóállításnak, a körforgásnak és a fogyasztásnak arra a ciklusára, amelynek révén a képmások jelentése felhalmozódik és átalakul"; a képmás materiális tulajdonságaira, s arra, hogy ez az anyagszerúség miképpen kapcsolódik a „nézés” (looking) társadalmi és történelmi folyamataihoz; a képmások kettós szemléletére, melyben a képmás jelentésközvetítésre alkalmas ábrázolás (representation) is, és az embereket örömszerzés céljából érdekló tárgy is; és arra, hogy a „nézés” (looking) inkarnálódott jelenség - „egy identitással rendelkezó személy cselekedete”. A vizuális jelentések tehát egy idóben perszonálisak, valamint a fentebb említett szélesebb kontextusok és folyamatok is keretezik óket. Ezek, a Lister és Wells (2000: 62-65.) által tömören összefoglalt témák egybecsengenek Rose és Banks fentebb kifejtett nézeteivel, ami arra utal, hogy a humán- és a társadalomtudományokban a képmások értelmezésének kritikai megközelítésmódjai szakítottak az oly sokat bírált pozitivista „igazságkereséssel” és objektiváló megközelítéssel, s talán egy új szemléletmód meghonosodását is jelzi a képmásokat értelmezó szaktudományokban.

Összefoglalva, Emmisontól és Smithtól eltéróen, akik nagyrészt megfigyelói megközelítést választanak, a vizuális képmások interpretációjának újabb megközelítésmódjai az antropológiában, a kultúrakutatásban és a kultúrgeográfiában egyaránt négy fó területet hangsúlyoznak. Kitartanak amellett, hogy a kutatás a következókre fordítson figyelmet: (a) arra a kontextusra, amelyben a képmás létrejött; (b) a képmás tartalmára; (c) azokra a kontextusokra és azokra a szubjektivitásokra, amelyekben és amelyek által a képmásokat szemlélik; (d) a képmások anyagiságára és közvetító anyagára (agency). De ami talán még fontosabb, a fentebb kifejtett gondolatmenet rámutatott, hogy annak a társadalomkutatónak, akit az emberek, a diskurzusok és a tárgyak közötti kapcsolat érdekel, fontos lehet a vizuális interpretáció ezen területeinek mindegyikére koncentrálni, mivel a megérteni kívánt vizuális jelentés gyakran e különbözó interpretációs területek találkozási pontjaiban helyezkedik el, s nem csak úgy „feltárul” egyetlen megközelítésmód révén.

\section{Reflexivitás és egy etikus vizuális metodológia}

A reflexivitás az egyik központi témakör a vizuális kutatás legújabb szakirodalmában, elmaradhatatlan eleme minden modern kutatási projektnek, s gyakran olyan pozitívumként emlegetik, amely megkülönbözteti a jó kutatást a rossztól, s ezzel az állásponttal én elvileg egyet is értek (lásd Pink 2001a). Ugyanakkor, 
ha meg akarjuk érteni, hogy a reflexivitás milyen módon van jelen a mostani szakmai vitákban, akkor különbséget kell tennünk a reflexivitással kapcsolatos eltéró állítások és használati módok között. A vizuális módszerek egyre gyarapodó szakirodalmában - ideértve az antropológiát (Banks 2001; Pink 2001a; Ruby 2000), a szociológiát (Emmison és Smith 2000), a geográfiát (Rose 2001), a deviancia-kutatást (Holliday 2001) és a multidiszciplináris megközelítésmódokat (van Leeuwen és Jewitt 2000) - a reflexivitást központi jelentóségúnek tekintik. Néha már az a benyomásunk, hogy versenyfutás folyik, hogy ki a leginkább reflexív - s ez a versenyfutás arra késztetett egyeseket, hogy a vizuális antropológiát kevésbé reflektáló, etikátlan és tárgyiasító (objectifying) praktikának minósítsék. Az ilyen vádaskodás részben az intellektuális párviadalok versengó szelleméból fakad, melyeknél a gyózelem megszokott eszköze az ellenfél diszkreditálása (lásd még Pink 2001b). Másik forrásuk a vizuális antropológiával, annak történelmi fejlódésével, valamint a szaktudományon belüli vitákkal és eszmecserékkel kapcsolatos ismeretek hiányossága. Az alábbiakban elóször a reflexivitásra való felszólítással foglalkozom a vizuális módszerekben. Azután pedig rátérek a vizuális antropológia néhány mai kritikájára.

A reflexivitás altémaként szerepel Rose (2001) Visual Methologies címú munkájában. Ennek minden fejezete értékeli a szóban forgó vizuális analízis megközelítésmódjának reflexivitását. Rose kimutatja, hogy a reflexivitás miképpen inkompatibilis egyes vizuális metodológiákkal; itt van például a tudományos tartalomelemzés (2001: 67.) és a szemiológiai irányzat, amely igyekszik „a felszini jelenségek mögé hatolni, bogy feltárja a képmások igazi jelentését" (2001: 98.), s amely azt állítja magáról, hogy „objektív ismertetéseket” produkál, s azokhoz nincs szükség a reflexivitásra. A reflexivitás „egyfajta önéletrajzként” magyarázza meg, hogy „a szerzó társadalmi pozíciója hogyan hatott arra, amit találtak”. A reflexivitás nem lehetséges a pszichoanalízisben, mivel az azt állítja, hogy nem lehetséges az ilyen reflexivitáshoz nélkülözhetetlen önismeret (2001: 130.). Hasonló módon a Foucault-féle diskurzusanalízis, amely feltárja a hatalom és az igazság eszméinek és diszkurzív formációinak szövegbe ágyazottságát, szintén „nem tud reflexí lenni” (2001: 142.), mivel az elemzó értelmezése nem tud többé objektívebb lenni annál, amit ó maga elemez (Rose 2001: 160.). Rose helyesen látja, hogy mivel ezek a metodológiák nem reflexívek, nem képesek kritikus vizuális metodológiaként funkcionálni. A reflexivitás ilyen hiányának ellensúlyozására azt javasolja, hogy mindig maradjunk tudatában azoknak a hatalmi viszonyoknak, amelyekben az általunk elemzett képmások is és mi, mint kutatók is részt veszünk, és érintettek vagyunk, hogy „biztosra vehessük, hogy leirrásunk felismeri mind a képmás szemléletmódjából, mind pedig a saját szemléletmódunkból fakadó differenciált hatásokat" (2001: 203.). 
Rose érvelése és kritikája helyénvaló, ugyanakkor nehéz feladatra vállalkozott, mivel interdiszciplináris kutatása megakadályozza ót abban, hogy a vizuális kutatásra azokat a modelleket alkalmazza, amelyeket egy konkrét diszciplína egy projekt számára javasol. Ahogy Banks megjegyzi: „A vizuális képmások kutatásának és használatának nem öncélként, hanem csak egy szélesebb szociológiai kutatási vállalkozás keretében van értéke, s a kutatási projekt általános elméleti kerete ilyen mértékben fogja befolyásolni az orientációt minden keletkezó vagy elóállitott vizuális képmás felé” (2001: 178.). Az „audiencingról” szóló fejtegetésében Rose az etnográfiát például a résztvevó megfigyelés olyan formájaként jellemzi, amelyben az etnográfus megfigyeli az adatközlóket, és beszél hozzájuk. Itt most elvész a reflexivitásra helyezett hangsúly, minthogy Rose tágabban nem köti össze fejtegetését a reflexív etnográfiai gyakorlat fejlódésével, amelyen belül a kutatók tudatában vannak annak, hogy miképpen szemlélnek és értelmeznek akkor, amikor az etnográfiát múvelik, s akkor is, amikor a képmásokat szemlélik. Rose ehelyett azt hangsúlyozza, hogy a képmásoknak megvan a maguk hatalma és hatása, s hogy a jelentések ilyenképpen a képmás és a szemléló közötti párbeszédben (negotiation) konstruálódnak meg. Az „audiencingnek” ez a folyamata az, amit Rose szerint tanulmányoznunk kell. Rose jogosan nehezményezi a reflexivitás hiányát a ma létezó megközelítésmódokban, és hasznos javaslatokkal szolgál, hogy a kutatók miképpen ellensúlyozhatják ezt. Antropológiai nézópontból azonban én úgy látom, hogy a képmás-interpretáció és -kutatás társadalmi kontextusának Rose-féle kifejtésében hasznos lett volna, ha a szerzó kissé elmélyül a reflexivitás vizuális antropológiai vonatkozásaiban. Ez a megközelítés a képmás és a szemléló közötti viszony kérdéskörét a kutató és a képmás, vagy a kutató és az adatközló közötti viszonnyá szélesítheti. Arról van szó ugyanis, hogy ha képmásokkal kapcsolatban készítünk interjút az adatközlókkel, figyelembe kell vennünk, hogy az interjúban szerepló képmások vagy anyagi tárgyak miképpen közvetítik a kutató és az adatközló közötti viszonyt. Banks nagyon jól rámutat az ilyen tudatosság fontosságára egy, a saját antropológiai terepmunkájából vett példával. Leírja, hogy amikor elóször folytatott vizsgálatot angliai otthonukban a dél-ázsiai bevándorlókkal, akkor azok mindig bekapcsolták a számára zavaró televíziót, miközben ó az interjúra igyekezett koncentrálni. Késóbb azonban rájött, hogy a televízió valószínúleg nem „egy irreleváns és zavaró tényezó", hanem „egy szociális beszélgetótárs”. Legutóbbi, Indiában készített interjúiban pedig felismerte, hogy ezek „háromoldalú informális interjūk, melyben a CNN Asia News tévébemondói azok, akik közvetítik köztem és adatközlóim között folyó beszélgetést a városban lezajlott legújabb gazdasági változásról" (2001: 14.). Banks arra is rámutat, hogy a reflexív megközelítés miképpen segítheti ezt a tudatosságot, saját középosztálybeli neveltetésével magyarázva a televízió iránti ellenérzéseit - hiszen az ó köreikben neveletlenségnek számít látogatók fogadásakor bekapcsolni a tévét. 
A reflexivitással kapcsolatban mások más megközelítésmódokat is javasolnak. Emmison és Smith szerint, ha a kutató „reflexivebb” és „módszertanilag tájékozott" a vizuális adatok használatában, az mindenképpen "javitja a kutatás minóségét" (2000: X.). Emmison és Smith reflexivitás-felfogása azonban különbözik például a Rubyhoz hasonló vizuális antropológusok felfogásától, akik azt hangsúlyozzák, hogy az etikai követelmények miatt a vizuális kutatásnak és ismertetésnek együttmúködốnek, reflexívnek és az adatközlók „hangját” reprezentálónak kell lennie. Emmison és Smith viszont nem etikai, hanem „érvényességi” kérdésként kezeli a reflexivitást. Ezzel szemben a vizuális antropológusok igen aktívan láttak hozzá a reflexivitás különbözó megközelítésmódjainak kidolgozásához a vizuális kutatásban. Ez legalábbis részben összefüggésben van a reflexív stílus kialakulásával az etnográfiai filmkészítésben; ezzel kapcsolatban általában David és Judith MacDougall 1970-es és 80-as évekbeli megfigyelói moziját (observational cinema) szokták emlegetni, amely az episztemológiai innovációk kontextusában fejlódött ki, ahol a filmkészítók „egyre nyiltabban beszéltek arról, hogy a filmek hogyan, miért és kiknek készültek" (Loizos 1993: 171.). MacDougall kijelentette, hogy a vizuális antropológusoknak mély és szerves síkon kell foglalkozniuk a reflexivitással. James Clifford (1986) nyomán kifejti, hogy „a "mély" reflexivitás fogalma megköveteli, hogy magában a munka konstrukciójában feltárjuk a szerzó pozicióját, bármilyenek legyenek is a külsó magyarázatok" (McDougall 1998: 89.). Ez azt jelenti, hogy a reflexivitás, mint a kutatás motívumainak, gyakorlatának és feltételeinek egyik magyarázata, nem elégséges. Helyette inkább fel kell ismerni a terepmunkás állandóan változó pozícióját, ahogy a kutatás halad elóre, és az illetó „különbségeket tapasztal a megértési szintekben is, és a terepmunkára oly jellemzó hangulati [mood] és kapcsolati [rapport] változásokban”. Ezt a gyakorlatot, mondja MacDougall, bele kell venni a filmbe, és ez többet képes elmondani a kutató/filmes (változó) perspektíváiról, mint amennyit az egyszerú, eseményutáni reflexió (1998: 89.). Tekintettel a reflexivitás taglalásának viszonylagos részletességére, amivel az antropológiai szakirodalomban MacDougall (1998) és Ruby (2000) múveiben találkozhatunk, eléggé meglepó, hogy más szaktudományok kommentátorai a vizuális antropológia egészét vádolták meg reflektálatlansággal. Emmison és Smith például nem a „reflektálatlan” (unreflexive) terminust alkalmazza a vizuális antropológiára, hanem azt állítja, hogy az (a vizuális szociológiával együtt) „nem tudott kapcsolódni e szaktudományok társadalomelméletének szélesebb áramlataihoz" (2000: 5.), és hogy a fotográfiát csupán illusztratív dokumentációs vagy archivációs anyagnak használja, ahelyett hogy analitikai módon közelítene hozzá. Ez a leírás távolról sem illik MacDougall fentebb említett reflexív megközelítésére, vagy a koloniális fotográfia jól ismert elemzó munkájára (1992). Holliday közvetlenebb módon azért bírálta a vizuális antropológiát, mert 
hangsúlyozza a vizualitás reflexivitását és a benne rejló lehetốségeket a deviancia-kutatásban. ${ }^{5}$ Néhány antropológiai alapmú Holliday-féle kritikája - dekontextualizálva óket a régi elméleti vitáktól, melynek részét alkotják - azt állítja, hogy az antropológiai jellegú reflexivitás „üres divatszóvá válik egy pszeudopozitivista megközelités keretein belül, amely még mindig a nagyobb fokú "igazság" és "objektivitás" elérésére törekszik" (2000: 507.). Holliday ugyan nem idéz elég konkrét példát álláspontja meggyốzóvé tételére, mégis van valami igazság abban, hogy a XX. századi vizuális antropológia reflektálatlan volt, az általa leírt módon. Mindazonáltal van néhány komoly probléma a vizuális antropológia Holliday-féle interpretációjával. Elóször is, Emmisonhoz és Smithhez hasonlóan figyelmen kívül hagyja azokat a témákat és vitákat, amelyek a vizuális antropológia fejlódésének utóbbi 25 évében jelentek meg. Idézve Mead 1975-ben írott bevezetójét Hocking 1995-ben újra kiadott gyúijteményes kötetéhez, Holliday kijelenti, hogy a vizuális antropológiában „a múvészi filmet és szöveget azzal vádolják, hogy aláássa az ilyen kutatások tudományos "szigorúságát'" (2000: 505.). Ezek a megállapítások nem helyezik el történetileg a bírált múvet, ami oda vezet, hogy Holliday az antropológiát mint segédtudományt úgy jellemzi, hogy az fenntart egy múvészet-tudomány dichotómiát, és olyan „objektív” és „tudományos” antropológiai filmeket igyekszik készíteni, amelyek kerülik a mozifilmek artisztikus szubjektivitását.

Az ilyen elemzéseknek van valami igazságuk abban, hogy találkozhatunk reflektálatlan munkával és a képek objektiváló illusztrációkként való használatával a - fóként a korai - vizuális antropológiában. Problémájuk az, hogy nem ismerik föl: a vezetó vizuális antropológusok már kidolgozták az ilyen munka elfogadott kritikáját. Egyebek közt Ruby kínálta az utóbbi bó 20 év alternatív szemléletét, amelyet a vizuális antropológia fentebb idézett bírálói figyelmen kívül hagytak (lásd Ruby 2000). Ráadásul a szakirodalom áttekintéséból kiderül, hogy sok olyan vizuális antropológus van Európában és az Egyesült Államokban, aki nyilvánvalóan reflexív és szubjektív módon használja a videót és a fotográfiát (pl. Ferrándiz 1998; Pink 1999; Pink et al., megjelenés elótt; Lutkehaus és Cool 1999).

Összefoglalva: a reflexivitás kulcsfontosságú téma a vizuális kutatással foglalkozó legújabb írásokban. De miközben a szerzók egyetértenek abban, hogy a reflexivitásnak alapvetó elemként jelen kell lennie minden projektben, a különbözó szaktudományokban dolgozó elméleti szakemberek már eltéróen vélekednek a reflexivitás megvalósithatóságáról és etikai implikációiról. A különféle megközelítésmódok általában azt hozták ki, hogy a reflexivitás az a megértési

\footnotetext{
${ }^{5}$ Holliday álláspontjával részletesebben foglalkoztam egy másik cikkben (Pink 2001b), s ebben a cikkben röviden visszatérek rá.
} 
igény, amelyben lényeges, hogy „honnan érkezik a kutató”, és hogy ez miképpen hat a megszerzett ismeretekre. Egyesek az érvényesség és a kutatási minóség kontrolljának kérdésére hagyatkoznak. A legtöbb vizuális antropológus azonban egészen más irányban tájékozódik. Azt mondják, hogy a reflexivitásnak maradéktalanul integrálódnia kell a terepmunka folyamataiba és a vizuális vagy írott bemutatásba, méghozzá olyan módokon, amelyek nem egyszerúen csak megmagyarázzák a kutató hozzáállását, hanem felfedik azokat a folyamatokat is, amelyek révén a kutató és az adatközló pozíciója konstituálódik, és amelyek révén az ismeretek a terepmunka során megszületnek.

\section{Megfigyelés vagy együttműködés: újjáéled az objektivitás-szubjektivitás-vita?}

Az objektivitás-szubjektivitás-vita fontos szakaszát jelentette a vizuális antropológia történetének, de manapság bizonyos mértékig már háttérbe szorult a diszciplína szakirodalmában. A vizuális metodológiával foglalkozó legújabb írások azonban felelevenítik a szubjektivitás-objektivitás-polémiát, méghozzá olyan kérdésként, amelyre a vizuális módszerek interdiszciplináris szakterületének kell megadnia a választ. Ebben a fejezetben ezeket a fejleményeket tekintem át.

A van Leeuwen és Jewitt által szerkesztett Handbook of Visual Research (A vizuális kutatás kézikönyve, 2000) nem kritikailag viszonyul a vizuális antropológiához. Egyáltalán mindenféle kritikától tartózkodik, azzal a tiszteletre méltó szándékkal, hogy különbözó tudományágak és megközelítésmódjaik egész sorát mutathassa be. Közben azonban elmulasztják bemutatni azokat az elméleti és módszertani különbségeket, vitákat és történeti fejleményeket, amelyek hatással vannak azokban a szaktudományokban a vizuális gyakorlatra. Kötetükben a vizuális antropológiát Collier Approaches to analysis in visual anthropology (Az elemzés megközelítésmódjai a vizuális antropológiában) címú tanulmánya képviseli. Collier azonban nem foglalkozik a vizualitás olyan antropológiai megközelítésmódjaival, amelyekre különbözó episztemológiai és módszertani eljárások és programok jellemzóek. Ehelyett a saját megközelítésmódja által vezetve írja le a vizuális elemzés különbözó módszereit. Ezt, a Collier és Collier Visual Anthropology (1986) címú múvében kifejtett megközelítésmódot folyamatosan kritizálták a kortárs vizuális antropológusok, és „egy nagyrészt közvetlen realista kereten belül múködó módszer és elemzés" (Edwards 1997: 53.) kalauzának tekintették. A vizuális antropológia ilyen realista megközelítésmódjai sajnálatosan bátorítják a szaktudomány mint objektiváló gyakorlat kritikáját is, és az olyan jellemzéseket is, mint például van Leeuwené és Jewitté, akik szerint a vizuális 
antropológia „vizuális felvételek használatával foglalkozik, specifikus közösségek mai és régebbi életmódjának leirása céljából" (2000: 2.).

Mint már láttuk, Emmison és Smith a „voyeurisztikus” és a „pornográf” kifejezésekkel jellemzi a pozitivista paradigma keretein belül dolgozó társadalomtudósok komoly munkáját. Az ilyen, szenzációhajhász terminológiára semmi szükség nincsen. Az ilyen képek elkészítésének és megcélzott közönségüknek az elemzése ugyanis azt mutatja, hogy ezek inkább az akadémiai tudástermeléshez tartoznak, nem pedig a pornográfia populáris közönségéhez. Ha hasznos akar lenni, akkor a pozitivista munka minden kritikájának az ilyen munkát információkkal ellátó, vizuális megfigyelói, realista megközelítésére kell irányulnia. A módszertani, s nem annyira az etikai alapoknak ez a kritikája lehetetlen volna Emmison és Smith gondolatmenetén belül, mivel az ó módszerük egy megfigyelói megközelítésmódon alapul. Emmison és Smith vizuális adatnak tekinti a megfigyelhetó emberi interakciót, az interakció kutatásáról pedig ezt írják: „Az emberek olyan jelzések (signs) hordozóiként való tanulmányozása, amelyek jelzik az identitást, a státust és a társadalmi kompetenciát" (2000: 190.). Azt tanácsolják, hogy a megfigyelók nem „tolakodó” (unobtrusive) megfigyelési módszereket alkalmazzanak. „E látható információforrások nagy elónye az, hogy lebetóvé teszi számunkra a társadalmi élet diszkrét megfigyelését”, és így „a normatív válaszolás (a kutatónak társadalmilag elfogadható válaszok adása) szokásos problémája nem jelentkezik”. Emmison és Smith szerint „gyakran elboldogulunk interjüzás nélkül is", habár tanácsos lehet hagyni az adatközlóket, „hogy elmagyarázzák a tárgyak és elhelyezkedésük jelentóségét, ami lehetóvé teszi a kutató számára a magyarázatok kiegészitését és a spekulatív következtetések érvényességének ellenórzését" (2000: 110.). Ez a módszer a vizuális rögzítési eljárásokkal szemben a jegyzetelést preferálja - a fényképezést és a videózást szükségtelennek tartja. Az egyik gyakorlatnál például azt javasolják, hogy a kutatók idegeneket szólítsanak meg az utcán, és igyekezzenek beszédbe elegyedni velük, miközben egy másik kutató jegyzeteket készít a válaszaikról. A kutató-adatközló interakciónak itt nem az a célja, hogy számot adjon az adatközló nézeteiról, hanem az, hogy ellenórizze az illetố válaszát. Az ilyen kvalitatív módszerek nagyban különböznek az ismeretszerzés vizuális antropológiai megközelítésmódjaitól. Alkalmasak lehetnek ugyan a nem tolakodó vizsgálatot folytatók számára, antropológiai nézópontból azonban naivul érzéketlenek lehetnek az iránt a gondolat iránt, hogy a dolgokat az teszi láthatóvá, ahogy nézzük óket, s nem egyszerúen, mert megfigyelhetók. Így aztán Emmison és Smith helytelenül állitja, hogy csakis az övék az elóremutató módszer a vizuális kutatásban, kijelentve, hogy ez már tökéletesebb a vizuális antropológia általuk régebben adott, pontatlan leírásánál. 
Az Emmison és Smith által javasolt megközelítésmóddal szemben a vizuális antropológusok már régen szakítottak a puszta megfigyeléssel, és hangsúlyozzák a fénykép- és videofelvételek készítésének interszubjektív és együttmúködố jellegét. Ahogy Banks megjegyzi: „Minden képmás a társadalomkutató által a terepen történó készitésének, de tulajdonképpen a közvetlen társadalomkutatás minden formájának bizonyos mértékig együttmúködō (collaborative) jellegúnek kell lennie”, mivel "már az is társadalmi alkuk sorozatának az eredménye, bogy a kutató jelen lehet egy embercsoporton belül" (2001: 119.). Még Mead Bali szigetén végzett megfigyeló fotós kutatása is együttmúködésre vezetett a kritikusként megnyilatkozó adatközlóivel. És valóban, a kutatás kollaboratív folyamatnak tekintése együtt jár a tisztán megfigyelối megközelítésmód kritikájával. Ennek oka elóször is az, hogy az utóbbi esetében a kutatás által érintett embereket tárgynak tekintik, míg az elóbbi esetében adatközlókkel dolgozunk, és igyekszünk megérteni és bemutatni álláspontjukat és tapasztalataikat. Másodszor pedig, míg a megfigyelói megközelítésmód a „valóságról” a láthatóság révén megszerezhetó információ elérhetóségére vonatkozó feltevésekre támaszkodik, addig a kollaboratív megközelítésmód azt demonstrálja, hogy a tudás és a tapasztalat milyen sok aspektusa nem látható, de még a látható vonatkozások is más-más jelentést hordoznak a különbözó emberek számára (lásd Pink 2001a: 23-24.). És végül, a vizuális antropológusok a képmás-elóállítást, a tárgyalásokat (negotiations) és az ezzel járó együttmúködést nem pusztán vizuális jegyzetkészítésnek tekintik, hanem azon folyamat részének, amelynek révén az ismeret létrejön. Az együttmúköódés fontos tényezó az embereket és a képmásokat érintố mindenféle projektben, mind etikai szempontból, mind pedig azon interszubjektivitás felismerési módjaként, amely minden emberi találkozás alapját képezi. Ahogy Banks összefoglalja: „Behatolni, afféle istenként, más emberek életébe és egy elóre meghatározott elméleti programnak megfelelóen "adatokat" (s köztük ,"vizuális adatokat is) gyūjteni, nos, ez szerintem nem egyszerúen morálisan kétes, de intellektuálisan is ingatag lábakon álló vállalkozás"(2001: 179.; lásd még Pink 2001a: 36-46.). Az együttmúködés néha nem terjed túl azon a kutatói ötleten, hogy a társadalomkutatási projekt céljainak elérése érdekében együttmúködésre kérjék fel az adatközlóket, néha viszont olyan projektekre is kiterjed, amelyekben az adatközlók érdekérvényesítési lehetóségekhez jutnak az olyan képek készülése révén, amelyek arra szolgálnak, hogy bemutassák óket, és támogassák az ó ügyüket. 


\section{Összefoglalás}

E tanulmány bevezetójében azt írtam, hogy az „íj” vizuális módszereknek, ahogyan azok a különbözó szaktudományok perspektíváiban megjelennek, közös érdeklódési területük a reflexivitás, az együttmúködés, az etika, valamint a képmások tartalma, kontextusa és anyagszerúsége (materiality) közötti viszonyok. Ugyanakkor e módszerek különböznek is egymástól mindezek definíciójában és alkalmazásában, ahogy igyekeznek elérni saját szaktudományos céljaikat. És itt jelentkezik az interdiszciplináris kritika egyik nehézsége. S bár én úgy látom, hogy a vizuális antropológia Emmison és Smith-féle kritikája hiányos ismereteken alapul és nem helytálló, ugyanakkor azt is elismerem, hogy ez a kritika olyan kutatókra vonatkozik, akiknek még nagyon különbözó volt a tudományos programjuk, mint a mai vizuális antropológusoké. Felvetettem, hogy az interszubjektivitás olyan vizuális antropológiai megközelítése, amelynek révén maga az etnográfiai ismeret megszületik, megerósíthetné Rose azzal kapcsolatos perspektíváját, hogy miképpen kutatható a jelentések létrejöttének folyamata az emberi és a képi tényezók, valamint az „audiencing” közötti alkuk (negotiation) során. Kritikámat olyan antropológusként fogalmaztam meg, akinek sajátos etnográfia- és reflexivitás-megközelítésmódja jelentốsen eltér azokétól, akik az audiencinget tanulmányozzák. Az interdiszciplináris kritika és az együttmúködés bonyolult dolog, és mindenféle érzékenységet sért. Közös érdeklódési területeink a jövóbeli együttmúködés és kölcsönös tanulás ígéretét hordozzák. De ez bizonyos fokú nyitottságot igényel, és azt, hogy megfelelóen tájékozottak legyünk egymás szaktudományának gondolatait és történeti fejlódését illetóen. A vizuális antropológia például az elméleti és módszertani innováció hosszú és megalapozott történelmével rendelkezik. A XX. században, amikor az antropológia akadémiai tudományággá vált, a vizuális antropológusok eleinte megpróbáltak helyet találni a vizualitás számára a maguk pozitivista realista projektjében. A XX. század vége felé azonban, különösen a Rouch-hoz és MacDougalls-hoz hasonló filmesek számára készült innovatív munkákkal (lásd Grimshaw 2001) a vizuális antropológusok elkezdtek szakítani azzal a tudományos paradigmával, hogy olyan munkákat produkáljanak, amelyek szubjektívek és reflexívek voltak, s az etnográfiai ismeretszerzés számára új vizuális irányokat kínáltak, s amelyek kihívást jelentettek a mainstream írott antropológia vizuális irányzatai számára.

Ahogy beléptünk a XXI. századba, legalább három tényezó kölcsönzött a vizualitásnak egyre kiemeltebb helyet az antropológiai kutatásban és leírásban: a reprezentáció válsága és a „writing culture” körüli vita, valamint a szubjektivitás és reflexivitás ezzel járó hangsúlyozása; egy újszerú odafordulás a vizuális és az antropológiai narratíva új típusai felé; és az új technikai lehetóségek. Ebben az új légkörben a vizuális antropológusok a fotózás, a videózás, a rajzo- 
lás és a hipermédia alkalmazásával folytatták az új, innovatív, reflexív és elméleti szempontból megalapozott projektek indítását (lásd Pink 2001a; Pink et al., megjelenés elótt). Ezek az új vállalkozások nem a semmiból léptek eló, hanem egy olyan segédtudomány (sub-discipline) színrelépésének folyományaként, amely a múltbeli tudományos antropológiával való bonyolult viszonyból fejlódött ki, hogy egyre kritikusabb szerepet játsszon a kortárs antropológiai elmélet és gyakorlat kialakításában. A más tudományágakban dolgozó vizuális kutatók mindent elkövetnek, hogy bekapcsolódhassanak ebbe az új munkafolyamatba - és a vizuális antropológia MacDougall, Edwards, Ruby, Grimshaw, Banks és Morphy, valamint mások írott és vizuális munkái által képviselt elméleti és módszertani innovációjának legújabb történelmébe - azáltal, hogy szilárdan elhelyezik a vizuális antropológia XX. század eleji múltját a maga történeti kontextusában.

\section{IRODALOM:}

ANG, I. 1985: Watching Dallas. London, Meuthen.

Banks, M. 2001: Visual Methods in Social Research. London, Sage.

Banks, M. and MoRphy (szerk.) 1997: Rethinking Visual Anthropology. New Haven, CT and London, Yale University Press.

Bateson, G. és Mead, M. 1942: Balinese Character: A Photographic Analysis. New York, New York Academy of Sciences.

Chaplin, E. 1994: Sociology and Visual Representations. London, Routledge.

CuIfFord, J. 1986: „Introduction: partial truths”. In J. Clifford és G. Marcus (szerk.): Writing Culture: The Poetics and Politics of Ethnography. Berkeley, Univesity of California Press, 2-19. (lásd magyarul: Cuiford, James 1994: Bevezetés. Részleges igazságok. Helikon, 1994/4.)

Collier, J. És Collier, M. 1986: Visual Anthropology: Photography as a Research Method. Albuquerque, University of New Mexico Press.

EDwards, E. (szerk.) 1997: Anthropology \& Photography 1860-1920. New Haven, CT - London: Yale University Press (közösen a londoni Royal Anthropological Institute-tal).

EDwards, E. 1997: „Beyond the Boundary”. In: M. Banks és H. Morphy (szerk.): Rethinking Visual Anthropology. New Haven, CT és London, Yale University Press, 53-80.

EDwARDS, E. 2001: Raw Histories: Photographs, Anthropology and Museums. Oxford, Berg.

EMmison, M. És Smith, P. 2000: Researching the Visual. London, Sage. 
Evans-Pritchard, E. E. 1940: The Nuer: A Description of the Modes of Livelihood and Political Institutions of a Nilotic People. Oxford, Oxford University Press.

FERRÁNDIZ, F. 1998: „A trace of fingerprints: displacements and textures in the use of ethnographic video in Venezuelan spiritism". Visual Anthropology Review, 13 (2): 19-38.

Fiske, J. 1994: „Audiencing”. In: N. K. Denzin és Y. S. Lincoln (szerk.): Handbook of Qualitative Methods. London, Sage, 189-198.

Gaines, J. M. 1999: „Introduction: the real returns”. In: J. M. Gaines és M. RenOv (szerk.): Collecting Visible Evidence. Minneapolis, University of Minnesota Press.

Grimshaw, A. 2001: The Etnographer's Eye. Cambridge, Cambridge University Press.

Hockings, P. (szerk.) 1995 [1975]: Principles of Visual Anthropology. 2. kiadás. Hága, Mouton.

Holliday, R. 2001: „We've been framed: visualising methodology”, The Sociological Review, 48 (4): 503-522.

HutNyK, J.: „Comparative anthropology and Evans-Pitchard's Nuer photography: photographic essay". Critique of Anthropology (Amsterdam), 1990, 10 (1): 81-102.

Lister, M. ÉS Wells, L. 2000: „Seeing beyond belief: cultural studies as an approach to analysing the visual". In: T. van LEEuven és C. JEwiTT (szerk.): Handbook of Visual Analysis. London, Sage, 61-91.

Loizos, P. 1993: Innovation in Ethnographic Film. Manchester, Manchester University Press.

Lutkehaus, N. ÉS CoOl, J. 1999: „Paradigms lost and found: the crisis of representation and visual anthropology". In: J. M. GAines és M. RENOv (szerk.): Collecting Visible Evidence. Minneapolis, University of Minnesota Press, 116-139.

MacDougall, D. 1998: Transcultural Cinema. Princeton, NJ., Princeton University Press.

McGuigan, J. 1997: Cultural Methodologies. London, Sage.

MEAD, M. 1995 [1975]: „Visual anthropology in a discipline of words”. In: P. Hockings (szerk.): Principles of Visual Antbropology, 2. kiadás. Hága, Mouton, 3-10.

Moore, H. 1999: „Anthropology at the turn of the century”. In: H. Moore (szerk.): Anthropological Theory Today. Oxford, Polity Press, 1-23.

MoOres, S.: Interpreting Audiences: The Ethnography of Media Consumption. London, Sage, 1993. 
Morley, D. 1992: Television, Audiences and Cultural Studies. London, Routledge.

Nichols, B. 1991: „Pornography, ethnography, and the discourses of power”. In: Representing Reality. Indiana University Press, 210-228.

Pauwels, L. 2000: „Taking the visual turn in research and scholarly communication". Visual Sociology, 15: 7-14.

PINK, S. 1999: „A woman, a camera and the world of bullfighting: visual culture, experience and the production of anthropological knowledge". Visual Anthropology, 13: 71-86.

PINK, S. 2001a: Doing Visual Ethnography: Images, Media and Representation in Research. London, Sage.

PINK, S. 2001b: „More visualising, more methodologies: on video, reflexivity and qualitative research". The Sociological Review, 49 (4): 586-599.

Pink, S., Kurti, L. és Afonso, A. I. (szerk.) 2004: Working Images. London, Routledge (megjelenés elótt).

Rony, F. 1996: The Third Eye: Race, Cinema, and Ethnographic Spectacle. Durham, NC, Duke University Press.

Rose, G. 2001: Visual Methodologies. London.

RuBY, J. 2000: Picturing Culture: Explorations of Film and Anthropology. Chicago, University of Chicago Press.

van Leeuwen, T. és JewitT, C. 2000: Handbook of Visual Analysis. London, Sage. 
18-sarahpink.qxd 2006.08.04. 11:22 Page 729

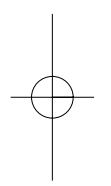


18-sarahpink.qxd 2006.08.04. 11:22 Page 730

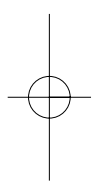

